УДК 811.111'276.6

\title{
Peculiarities of Medical Discourse in Professional and Non-Professional Settings
}

\section{T. V. Rodionova, I. V. Privalova}

Tatiana V. Rodionova, https://orcid.org/0000-0002-7431-2950, I. V. Ruzumovsky Saratov State Medical University, 112 Bolshaya Kazachia St., Saratov 410012, Russia, Rodionova.TVsar@yandex.ru

Irina V. Privalova, https://orcid.org/0000-0002-7740-2185, I. V. Ruzumovsky Saratov State Medical University, 112 Bolshaya Kazachia St., Saratov 410012, Russia, ivprivalova@mail.ru

The article discusses structural and functional differences between the medical discourses that are used in professional and non-professional settings. Having analyzed over 51,000 word usages, the authors conclude that the most significant differences are: the organization of the synonymous sets of the hyperonym 'Disease', the design of paradigmatic and syntagmatic connections, and the application of slang words and expressions.

Keywords: medical discourse, synonymic chain, syntagmatic and paradigmatic connections, hyperonym.

\section{Особенности профессионального и обыденного медицинского дискурсов}

\section{Т. В. Родионова, И. В. Привалова}

Родионова Татьяна Вячеславовна, старший преподаватель кафедры иностранных языков, Саратовский государственный медицинский университет им. В. И. Разумовского, rodionova.tvsar@ yandex.ru

Привалова Ирина Владимировна, доктор филологических наук, профессор кафедры русского и латинского языков, Саратовский государственный медицинский университет им. В. И. Разумовского, ivprivalova@mail.ru

В статье обсуждаются структурно-функциональные отличия между профессиональным и обыденным медицинским дискурсами. На основе анализа более 51000 словоупотреблений делается вывод о том, что наиболее показательными расхождениями являются: организация синонимического ряда гиперонима «Болезнь», оформление парадигматических и синтагматических связей, а также способы использования сленговых слов и выражений.

Ключевые слова: медицинский дискурс, синонимический ряд, синтагматические и парадигматические связи, гипероним.

DOI: https://doi.org/10.18500/1817-7115-2020-20-1-39-43

\section{Introduction}

In this paper, the concept of "discourse" is understood as a textual integrity in real-life conditions of its usage. Both text and discourse represent a super-phrasal unity, a set of statements united by a common idea and syntactic organization. Howev-

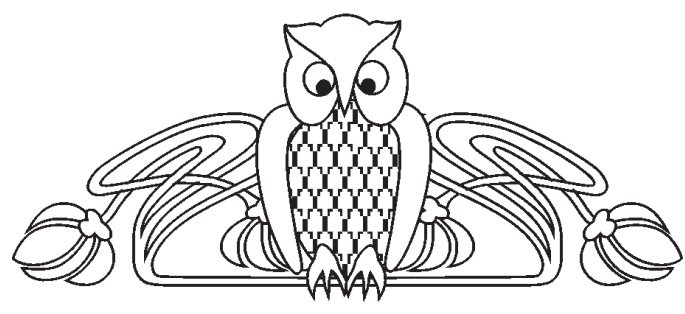

er, there is something that makes text and discourse possess disparate phenomena. Specifically, text and discourse are differently involved in procedures of communication and information exchange; in other words, they play dissimilar roles in the communicative process. In the situation of ceremonial communication, text is interpreted as institutional discourse [1, p. 25]. Institutional discourse happens to function under very peculiar conditions which predetermine its specificity. The types of institutional discourse are distinguished depending on the social institution in which an interaction takes place. So, it is proposed to single out political, diplomatic, administrative, legal, military, pedagogical, religious, mystical, business, advertising, sports, scientific, and media discourses [2, p. 7]. This paper is aimed at studying a special type of discourse, namely, medical.

\section{Theoretical Considerations}

Apparently, differentiation of various types of institutional discourse is believed to be conventional since the boundaries of each type are fuzzy. Medical discourse sets the patterns of a complex institutional discourse that may have the signs of scientific, administrative, mass media and advertising discourses. Hence, it is possible to distinguish such subtypes of medical discourse as: scientific medical discourse, educational medical discourse, administrative medical discourse, informative medical discourse, and advertising medical discourse. The existence of different types of medical discourse is the result of inter-discourse hierarchical interaction in which several types of discourse can take part, but one of the discourses occupies a dominant position [3, p. 171]. Moreover, inter-discourse interaction has become a much more frequent phenomenon than mono-discursive practices in modern sociolinguistic and pragma-linguistic reality.

As examples of medical scientific discourse, one may consider the texts and the scripts of lectures in different spheres of medicine: anatomy, physiology, pharmacology, faculty surgery, ophthalmology, neurology, etc. A scientific report presented at a symposium or at a medical conference is another genre of scientific medical discourse, as well as textbooks. At this certain point it is worth noting that textbooks also represent a genre of pedagogical discourse, thus proving the fact that the boundaries between various types of institutional discourses are not quite definite and even vague. 
The documents that regulate the relations in the field of healthcare, illustrate administrative medical discourse. Medical advertising media texts serve as a model of a medical media discourse with features of a mass media informative discourse. For instance, medical advertisement has in purpose the promotion of medications and services, which are directly related to health as a significant concept that possesses a dominant value in all cultures [4, p. 7].

High evolutionary potential is another hallmark of institutional medical discourse. The development of new medical discourses and discursive practices takes place on daily basis, and it happens primarily due to introduction of modern electronic channels and e-forms of communication. "The inclusion of new communication technologies into social practices creates opportunities for their evolution. This tendency also triggers the development of such forms of organizational activities in the institutional space of medicine as: telemedicine, the Internet medicine, and e-health" [5, p. 381] (the translation of the quote from Russian into English has been made by the authors). Within the framework of electronic medical discourse, there are formed new speech genres that are associated with unique speech events, for example, professional forums and semi-popular medical e-communication. In addition, the changes, which take place in social practices, stimulate the creation of such new genres of electronic medical discourse as medical instructions. These instructions increase the level of general medical literacy. Among other new genres of electronic medical discourse one can also mention descriptions of pharmaceuticals, electronic snapshots of diagnostic methods and medical equipment. The trends in self-diagnosis and self-treatment become more and more popular in the systems of healthcare of many countries in the world. It happens due to electronic accessibility to disease control counseling [6, p. 144].

The institutionalization of discourse cannot live without taking into account the status of interlocutors as well as the conditions in which their interaction takes place. In institutional medical discourse, there can be two types of statuses of interlocutors: the status of equal participants (doctor - doctor) and the status of unequal participants (doctor - patient). Respectively, they qualify status-oriented discourse and personality-oriented discourse [1, p. 28]. As far as the opposition "a specialist - a non-specialist" is concerned, N. D. Golev and N. N. Shpilnaiy propose to distinguish between professional medical discourse and ordinary medical discourse. This opposition reflects the opposition of scientific knowledge and naive knowledge [7, p. 129]. Noteworthy, communication of participants with equal status can take place both in formal and in informal settings. In this regard, we suggest making a distinction between professional and quasi-professional discourse when professional interlocutors converse in informal circumstances or when a medical worker interacts with a non-specialist.
In addition, one should take into account the form in which discourse is presented - oral or written. Oral discourse is manifestation of everyday speech and it functions in social contexts of "natural origin" [8, p. 181]. The written form of discourse is characterized by special features, namely, conciseness, clarity, and consistency. A scientific written discourse is marked by the use of terminology and special syntactic design.

\section{Practical Findings}

As seen, different kinds of medical discourse are marked with incoherence, and the main purpose of our study is to determine structural and functional differences between scientific (professional) oral discourse and quasi-professional oral discourse. The material of our research is the collection of transcripts of professional conversations and transcripts of medical conversations with non-professionals. Scientific discourse of physicians has been studied on the basis of audio recordings of lectures that have been delivered by professors of I. V. Ruzumovsky Saratov State Medical University to graduate medical students. The total amount of lexical units under investigation is 25085 . Non-scientific discourse has been studied on the basis of audio recordings of spontaneous, informal conversations of physicians with each other and the transcripts of conversations of one of the authors of this study (T. V. Rodionova) with the doctors of various specialties (therapists, surgeons, obstetricians-gynecologists, pediatricians, traumatologists, etc.). The total amount of lexical units related to this category is 24594 . In terms of syntactic configurations, the considered material is represented by monologues, dialogues and mini-narratives (the term "mini-narrative" describes short monologues of doctors on various topics [9, 10]). Medical discourse is a versatile phenomenon; that is why scholars are engaged into research of its various aspects, such as the use of terms or stylistic originality. Field arrangement of lexical units around the hyperonym "disease" has also been fully described $[11,12]$. In this study, we will focus on peculiarities of the lexical, grammatical and stylistic design of oral professional and quasi-professional discourses. The outlined focus of the research has predetermined the choice of the methods, namely: descriptive, comparative (within the same language system) and semantic-stylistic.

First, let us consider the specifics of the use of the most frequent lexical units in the matched discourses. Language units, which name various disorders and pathologies, are of the highest popularity both in professional and quasi-professional discourses. However, in medical discourse in non-official setting, the most frequent is the lexeme "sickness" whereas in the communication of professionals, it is "disease". As expected, the set of semantically related lexemes are more diverse in professional speech. In colloquial speech, only three quasi-syno- 
nyms of the words "disease" are used, and they are: "disorder", "impairment", and "pathology". In scientific medical communication, six units have been recorded: "disorder", "impairment", "deterioration", "malady", "pathology", "anomaly". In quasi-professional communication, the most popular synonym of the hyperonym "disease" is the lexical unit "pathology" (патология): ...Каждый триместр [беременности] может иметь свою патологию, и не только пиелонефрит...; А рентген может не обязательно патологию в легких только выявить, не обязательно только туберкулез, например, ...

Interestingly enough, in quasi-professional discourse, there is no detailed classification of diseases as this is not necessary. Comprehensive consideration of specific subtypes and forms of diseases is irrelevant since interlocutors discuss only what they already know and they understand each other without further ado. Conversely, in professional discourse, the names of diseases are specified according to various factors. The classification of the types of diseases draws on two parameters: a) pain localization, and b) branches of medicine dealing with diagnostics and treatment. For example: injuries (trauma, burn, dislocation); cardiovascular disorders (hypertension, dystonia, angina pectoris); endocrine disorders (diabetes); neurological disorders (arachnoiditis, narcolepsy, dyscirculatory encephalopathy); respiratory tract diseases (bronchitis, acute respiratory infections); purulent-septic diseases (gangrene, pulmonary tuberculosis); proctologic diseases (hemorrhoids); allergic and skin diseases (allergies, urticaria, diathesis); oncological diseases (sarcoidosis, tumor, cancer); urological diseases (pyelonephritis); substance abuse (alcoholism).

Second, in addition to the differences in the synonymous design of the hyperonym "disease", we have noted an important dissimilarity in the use of syntactic structures. Formalization of syntactic constructions reveals some varieties in professional and quasi-professional discourses as well. The distinctions between professional and quasi-professional medical discourses are manifested in the ways of arranging syntagmatic and paradigmatic connections.

Initially, we are going to consider the specificity of syntagmatic connections in two kinds of medical discourses under investigation. As for quasi-professional medical discourse, the most typical models of syntagmatic connections are: $\mathrm{A}+\mathrm{N}$ (asymptomatic disease, interesting / actual pathology, severe pathology, pulmonary disorders, structural disorders); $\mathrm{N} 1+$ (preposition) + N2 (pathology in the lungs). Most often, the additional members of the syntagmatic chain are the words related to the semantic field "Corporal" (pulmonary disorders, pathology in the lungs); to the semantic field "Evaluation" (interesting / current / severe pathology); or to the semantic field "Symptoms of disease" (asymptomatic disease). Weak syntagmatic connections are quite frequently ob- served in this type of discourse: ...A стресс сейчас ведь, ну, над всеми болезнями первый фактор...; ...З Зесь она такая пассивная (на видеокассете), это после болезни...; ...В садик сейчас не ходят дети только из-за болезни ...; ...Туберкулез - это именно то заболевание, которое много видно и мало исследовано...; ...Пришел дед с таким вот расстройством. Что-то у него там с почками. Кровь в моче...

Syntagmatics of language units describing various types of diseases in medical discourse in informal setting are fundamentally different from syntagmatics of units in oral scientific speech of physicians. The main syntagmatic model in colloquial speech is the model: $\mathrm{V}+$ (preposition) $+\mathrm{N}$ (to die from wounds, predisposed to allergies, dislocate to the right, earn hemorrhoids, sew up wounds, listen to [tube] bronchitis, etc.). This is due to the fact that colloquial speech is characterized by the use of a greater number of verbal structures as compared to scientific discourse.

As far as paradigmatic connections are concerned, the following should be mentioned. In quasi-professional medical discourse, the main type of paradigmatic connections is based on the gender-aspect relationship between the lexical units. The lexical units form an "itemizing opposition" when a general term is specified by a more concrete one: "trauma" stands for "burn", "wound", "dislocation". The opposition can also be formed by the units that are synonymous and quasi-synonymous: "disease" stands for "arachnoiditis", "bronchitis", "acute respiratory disease", "angina", "diathesis", etc. "Ailment" can mean "diabetes", "urticarial fever", "hypertension" and "pathology" may substitute such terms as "tuberculosis" and "pyelonephritis".

Also, there may be a formal semantic opposition: diathesis $\rightarrow$ diathetic, tuberculosis $\rightarrow$ tubercular. In such cases, adjective-derivative names preserve their initial lexical meaning: ...Классические симптомы - румяные щеки у туберкулезных больных... (= in patients with tuberculosis), ...Да, апельсины, мандарины - это все диатезные дела... (= products causing manifestation of diathesis). Interestingly enough, there are no equivalent semantic oppositions in quasi-professional medical communication since there is no point in detailed classification of diseases according to their subtypes. Besides, we have not noted any homonymous and paronymic relationship between language units. Synonymous relations are represented by one example only: ...Туберкулез это инфекиионное заболевание все-таки.

In the medical discourse that takes place in non-profession setting, one can notice the cases of stylistic synonymity, when, for example, the word "disease" is replaced by one of the slang words ("sore", "bad place", or "weak spot"): Больной живет себе и не знает, а потом у него резко эта болячка вдруг появилась... This is a case of stylistic synonymy; so far no semantic identity is inherent in synonymous relations. 
Indeed, the use of slang words, of new word building elements and colloquial expressions is a typical feature of every oral discourse and quasi-professional medical discourse is not an exception in this case. For instance, the hyperonym-lexeme "patient" is replaced by its stylistically clarifying hyponyms, which represent the units of colloquial vocabulary: a patient with asthenia is named as "thin and tall body type"; a patient with asthma is described as "asthmatic"; a patient with hypertension is called as "high blood pressure sufferer"; a patient with gastric ulcer is named as "an ulcer sufferer" or "an ulcerous person"; the so-called pet forms of a patient with the name of his disease are formed according to the model: name of the disease + Russian diminutive suffix: astma+tic, diabet+ic and so on. Most of the so-hyponyms (words with completely or partially coinciding meanings) contain a common element "disease" and popular morphemes: either the suffix "-іс (-ик)" (allergic, alcoholic, diabetic, neurasthenic, hypertonic, etc.) or the suffix "- chik (-чик)" (bronchit-chik, gastrit-chik, prostatit-chik). As far as the application of slang words is concerned, semantic opposition is observed in cases where the gender of the patient is indicated: neurasthenic - neurasthenic woman (неврастеник - неврастеничка); psychopath - psychopath woman (ncuxonam психопатка). And two cases have been recorded with the opposition to semantic identity: alcoholic - drunkard; psychopath - psycho.

The subject of disease can be named with lexical units that develop new meanings in the situation of medical communication in informal setting. Let us consider the examples with such words as: "client" (клиент), "suicide bomber" (смертник), "shell" (ракушка), and “Chernobyl veteran” (чернобылец). In the speech of physicians in informal setting, the above mentioned words appear in the new meanings. "Client" is a deceased patient who must be taken to a hospital morgue in order to make an epicrisis (a medical assessment report about the death of the patient): ...Сидим в ординаторской, заходит медбрат и говорит: "Всё, клиент готов, везите на вскрытие». The slang word "suicide bomber" is used to describe a patient who cannot survive and will die soon from his injuries or illnesses: ...B нашем нейрохирургическом отделении лежат сейчас одни смертники: кому голову проломили, кому мозги отстрелили...

Interestingly enough, the word "client", as well as the word "suicide bomber", is used by medical workers of the neurosurgical department where the most seriously ill patients are treated. So, the following assumption can be made concerning the use of these slang words. In the neurosurgical department, the relatives of some patients watch at their sickbeds, these people can step by into the doctors' residency and they may overhear some pieces of professional conversations. And it is in such cases that physicians use the word "client", which, apparently, is a euphemism for the words "deceased", "corpse", "departed".
Presumably, allegorical words help doctors to support the hope for recovery in other patients and in their relatives. It is also true with regard to such words as "shell" (a euphemism for "a cancer patient") and "Chernobyl veteran" (as a euphemism for a patient suffering from the consequences of radioactive exposure in Chernobyl). These slang words, in non-formal medical discourse, have developed the semes associated with a particular disease: В онкологии врачи называют своих больньх ракушками, да и сами больные, наверное, знают это название. The word "shell" is predominantly used by oncologists whereas the word "suicide bomber" - by neurologists. As for the slang lexical unit "a Chernobyl (cleanup) veteran", it denotes a person who has been involved in liquidation of the accident at the Chernobyl nuclear power plant. From the point of view of doctors, this is a special category of patients suffering from a number of diseases and who are in need to legalize their disability $(. . . И$ вообще, - сказала участковый врач, - вот, у меня муж тоже чернобылеи, а у меня ничего не получается с оформлением его инвалидности...). So, the range of popularity of particular slang words depends on the sphere of their application. The lexical units "suicide bomber" and "shell" are used by physicians of particular specialties, while the word "Chernobyl veteran" is widely applied by all medical workers.

\section{Conclusion}

All in all, the paper has discussed some peculiarities of medical discourse in professional and non-professional settings. Changes in extra-medical reality have generated the appearance of new forms of medical discourse. Modern medical discourse demonstrates various forms of its existence depending on the circumstances under which it is used. Medical discourse in informal setting is suggested being qualified as quasi-professional discourse when professional interlocutors converse in informal circumstances or when a medical worker interacts with a non-specialist. This kind of discourse is marked by a number of distinctions. We have considered such characteristic features as the synonymous design of the hyperonym "disease" and the ways of forming syntagmatic and paradigmatic connections on the lexical level in various semantic groups. Models of syntagmatic connections are incompatible in professional and quasi-professional medical discourses. The paradigmatic connections between the language units in the speech of physicians in non-professional setting are not really diverse and abundant. Meanwhile, in scientific medical discourse, a large number of the privative oppositions and equivalent semantic oppositions are noted, as well as oppositions of semantic identity which are represented by the cases of absolute synonymy and homonymy. 


\section{References}

1 Karasik V. The Structure of Institutional Discourse. In: Problemy rechevoi kommunikatsii. Mezhvuzovskiy sbornik nauchnykh trudov [Problems of Speech Communication. Inter-university collection of research papers]. Saratov, 2000, pp. 25-33 (in Russian).

2 Karasik V. On types of discourse. In: Yazykovaya lichnost': institutsional'nyi i personal'nyi diskurs [Language personality: Institutional and personal discourse]. Volgograd, 2000, pp. 5-20 (in Russian).

3 Shamne L., Shishkina E. The vocabulary of science-popular medical discourse (as exemplified in German online media). Science Journal of VolSU. Linguistics, 2018, vol. 17, no. 4, pp. 170-179 (in Russian). DOI: https://doi.org/10.15688/ jvolsu2.2018.4.16

4 Shmeleva O. Spetsifika vozdeistviya meditsinskoi i kosmeticheskoi reklamy v sovremennom kitaiskom i russkom mediadiskurse [Specificity of the impact of medical and cosmetic advertising in modern Chinese and Russian media selection]. Thesis Diss. Cand. Sci. (Philol.). Moscow, 2017. 27 p. (in Russian).

5 Grishechkina N. Transdisciplinary Knowledge as a Factor of Medicine Development in Modern Society. Izv. Saratov Univ. (N. S.), Ser. Philosophy. Psychology. Pedagogy, 2017, vol. 17, iss. 4, pp. 379-383 (in Russian). DOI: 10.18500/1819-7671-2017-17-4-379-383

6 Shamne N., Shishkina E. German popular scientific medical online media: structural and functional aspects.
Science Journal of VolSU. Linguistics, 2017, vol. 16, no. 2 , pp. 143-151 (in Russian). DOI: https://doi.org/10.15688/ jvolsu2.2017.2.15

7 Golev N., Shpilnaiy N. Ordinary Medical Communication (types of discursive practices). Bulletin of Kemerovo State University, 2012, no. 1, pp. 128-137 (in Russian).

8 Shpilnaya N. Axiological dominants of the female student oral discourse (on the material of everyday dialogue). Siberian Journal of Philology, 2018, no. 2, pp. 170-184 (in Russian). DOI: https://doi.org/10.17223/18137083/63/15

9 Zhura V. Narratological Studies of Oral Medical Discourse. Mezhdunarodnyj zhurnal issledovaniy kul 'tury [International Journal of Cultural Studies], 2013, no. 1 (10), pp. 72-78 (in Russian).

10 Zhura V., Martinson J. Narratological Approach to Medical Discourse. In: Aktual'nye problemy sovremennoi gumanitarnoi nauki: otechestvennye traditsii i mezhdunarodnaya praktika [Actual Problems of Modern Humanitarian Science: Domestic Traditions and International Practice]. Simferopol, 2017, pp. 34-41 (in Russian).

11 Rodionova T. Peculiarities of the Lexico-Semantic Field «Disease» in the Oral form of Scientific Medical Discourse. Izv. Saratov Univ. (N. S.), Ser. Philology. Journalism, 2012, vol. 12, iss. 1, pp. 42-46 (in Russian).

12 Rodionova T. Specific Features of the Lexico-semantic Field «Disease» in the Written Form of Scientific Medical Discourse. Izv. Saratov Univ. (N. S.), Ser. Philology. Journalism, 2011, vol. 11, iss. 2, pp. 28-31 (in Russian).

\section{Образец для цитирования:}

Rodionova T. V., Privalova I. V. Peculiarities of Medical Discourse in Professional and Non-Professional Settings [Pодионова T. В., Привалова И. В. Особенности профессионального и обыденного медицинского дискурсов] // Изв. Сарат. ун-та. Нов. сер. Cер. Филология. Журналистика. 2020. T. 20, вып. 1. С. 39-43. DOI: https://doi.org/10.18500/1817-7115-2020-20-1-39-43

\section{Cite this article as:}

Rodionova T. V., Privalova I. V. Peculiarities of Medical Discourse in Professional and Non-Professional Settings. Izv. Saratov Univ. (N. S.), Ser. Philology. Journalism, 2020, vol. 20, iss. 1, pp. 39-43. DOI: https://doi.org/10.18500/1817-7115-2020-20-1-39-43 